\title{
Bager
}

\section{Når jorden hvisker sit navn}

Anmeldt af Lea Siewertsen

Anmelderen er lidt skeptisk over for en miniserie bestående af 6 hæfter med historier om forskellige geologiske temaer for børn - fakta og fiktion blandes med forvirring til følge.

Når jorden hvisker sit navn, er en serie af mindre hæfter om forskellige naturvidenskabelige fænomener sat ind i nogle meget underfundige fortællinger. Forfatteren Jytte Grådal er pædagog, lyriker og museumsassistent på Fur Naturhistoriske Museum.

Hun har udviklet sin formidlingsform gennem sit arbejde på museet med de skoleklasser, der har besøgt stedet. Senere hen er det så blevet til disse hæfter, hvortil Lis Kohl bidrager med sine hovedsageligt abstrakte illustrationer.

\section{Fordele og ulemper}

Fortællingerne henvender sig primært til bør-

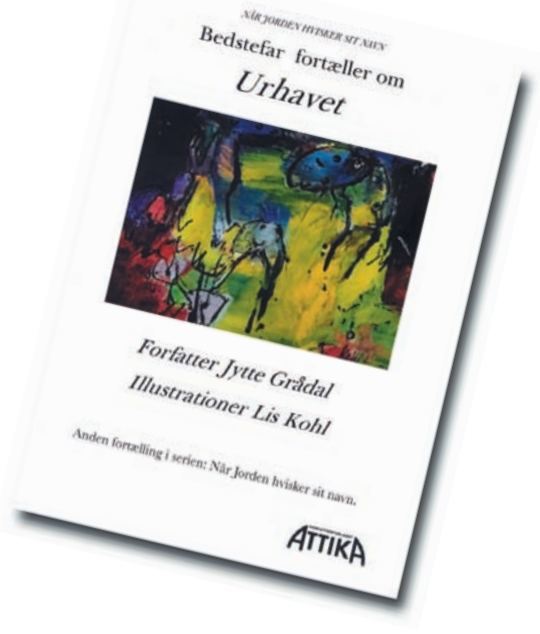

nehaver og børnehaveklasser.

Historierne tager udgangspunkt i forskellige emner: dinosaurer, urhavet, vulkaner, blæksprutter og Danmark. Man skal dog ikke forvente at få en faktuel gennemgang af det pågældende emne. Derimod får man en fantasifuld historie, der sikkert vil fænge målgruppen. Dette er på en gang historiernes styrke og svaghed. Fordelen er, at historierne sikkert vil appellere til børnenes fantasi, ulempen er, at fakta og fiktion blandes, således at det vil være svært for børn at skelne, hvad der er hvad. I forlængelse heraf, kan man spørge, hvad målet med hæfterne er? Er det oplysning, eller er det "bare" at give en god historie?

Ved at vælge en blanding af de to, som forfatteren gør, taber man det naturvidenskabelige indhold og bidrager til opbygningen af forestillinger hos børnene, der ikke har hold i virkeligheden.

Forfatter er Jytte Grådal med illustrationer af Lis Kohl. Forlaget er Attika, og bøgerne kan købes via forlaget: attika@attika.dk. Pris pr.stk.98 kr. Hele serien 325 kr. 